\title{
IMPACT OF LEADERSHIP ON ORGANISATIONAL OUTCOMES IN SCHOOL MANAGEMENT - EXAMPLE OF BOSNIA AND HERZEGOVINA
}

\author{
UDC: $005.322: 316.46]: 371.113(497.6)$ \\ Original Scientific Paper \\ Edin STRUKAN ${ }^{1}$, Adnan KRESO ${ }^{2}$, Denis FAZLIĆ ${ }^{3}$ \\ ${ }^{1}$ PI Pedagogical Institute of the Una-Sana Canton, Maka Dizdara 3, 77000 Bihać, Bosnia and Hezegovina. \\ E-mail: strukan.s@missnet.ba \\ ${ }^{2}$ Ministry of Education, Science, Culture and Sports of the Una-Sana Canton, Alije Đerzeleza 6, 77000 Bihać, \\ Bosnia and Hezegovina. \\ ${ }^{3}$ Agency for pre-primary, primary and secondary education B\&H, Stepe Stepanovića 99, 78000 Banja Luka, Bosnia \\ and Hezegovina
}

Paper received: 20.10.2014.; Paper accepted: 11.12.2014.

\begin{abstract}
The paper presents some organisational outcomes in school management that are strongly interrelated, and leadership which has a significant impact on them. Considering the fact that the school is a non-profit organisation with a specific social significance, the aim of the research was to determine how to improve the results of the school management, or to determine how to improve the management of the school by the school principal, and thus to improve key organisational outcomes: school quality, job satisfaction, organisational (school) culture and work motivation. The survey was conducted during the first half of 2014 (January, February, March) in 23 secondary schools in Una-Sana Canton ( $\mathrm{B}$ and $\mathrm{H}$ ), by the method of survey and interviewing, using the questionnaire as an instrument of scientific research. The above outcomes significantly affect key organisational outcomes of the educational process, pupils' achievement, which are measured by their success in learning and behaviour.
\end{abstract}

Key words: leadership, motivation, quality, job satisfaction, school culture, B and H.

\section{INTRODUCTION}

The main reason why this study has been conducted, was to derive the relevant indicators and determine to what extent the development of leadership competences with school principals, who formally and substantively represent school management, impact the organisational performances and organisational outcomes, of which the most important pupils achievement are in learning and behaviour, that actually represents a summary of the results of all activities in the educational process.

Despite the great importance and expansion of leadership as a science in the last three decades, conducted empirical research on the topic of leadership in the countries of the region are not common, therefore the aim of this study was to gain certain knowledge about leadership as a process by which leading managers create certain interaction with their employees and transmit all the required knowledge to them, motivating them to achieve better operating results (Buble, 2010).

Another reason why this study has been conducted was to derive relevant indicators and determine the extent to which the leadership of school principals influences the selection of working style and prioritizing the conduct in relation to the standard management control. Also, the aim was to determine whether leadership can improve the results of the key (human) resources in school, as well as the correlation of job satisfaction, motivation, and organisational (school) culture with the quality and student achievement. Namely, in order to combine human resources properly into a quality organisational unit that will have good results, it is preferable that they are satisfied and 
motivated to work, because it implies greater efficiency and effectiveness.

Although educational establishments are essentially engaged in socially useful activities, they are also business organisations whose main resource is workforce which includes teaching and non-teaching staff, and the function of their management and leadership with an aim of achieving educational outcomes is assigned to school principals as the main coordinators of all activities. Therefore, school principals are managers in the non-profit sector but their responsibility for the quality management of the organisation is not less than that of a manager in the for-profit sector. It is written in most of the literature in this area that managers are doing the right things, and leaders are doing things the right way, stating that an organisation should have both: a good manager and a good leader and that they are not competitors to each other but are complementary, but each with their position and role: manager is an administrator while leader is an innovator, manager maintains, the leader develops, manager focuses on systems and structure, while the leader focuses on the people, manager develops control while leader develops confidence, manager works with a certainty, leader with a probability, manager deals with the present while leader with the future. Thus, managers and leaders are very different (Zaleznik, 2004), a leader is a person who takes responsibility (planning and implementing a vision in which he believes), and who coordinates the activities of people in their efforts to achieve their goal (Bass, 1981). Regardless of which leadership it is about, Gardner has defined six characteristics of leadership: story, the audience, organisation, personification, oratory, skills (Gardner, 1996). According to most authors in this field, leadership plays a more significant role than the standard manager control, because the management is the static form of determining the direction of organisational movement, and leadership necessarily has a form of dynamic movement toward a goal that can be defined as the dynamic changes in order to achieve greater market competitiveness (Collins, 2007). Bennis and Nanus state that effective leaders have four common characteristics: provide guidance and set goals and objectives, create confidence in the environment, take the risk and communicate effectively (Bennis and Nanus, 1985).

\section{Motivation as an organisational outcome of school}

When it comes to motivation as an organisational outcome, great importance for the motivation achievement of employees to work in schools is given to the pattern of behaviour of their Principles, because depending on the pattern, leadership styles may be different, and more or less affect the level of motivation of employees. Keeping in mind the variety of models and styles of leadership role, four basic types of leader's behaviour can be extracted: supportive, participative, directive and charismatic, whereby the effectiveness of each of these types is conditioned by situational factors, largely by the characteristics of the tasks, organisation and employees (Howell and Costley, 2001). Despite the fact that the leaders pay more attention to the motivation of human resources, it should be pointed out that motivation is one of the things leaders like to talk about rather than to apply it in practice (Wren and Voich, 2001). Today, it is considered that the greatest quality of a leader is his ability to solve complex issues of motivation of employees, which improves the efficiency and effectiveness of their work, their creativity, as well as other organisational performance. To make the organisation operate successfully, its managers need to find the optimal combination of tangible and intangible incentives for their employees, and the optimal combination depends on many factors, for example the structure of employment, the sector in which the organisation operates, etc. Any strategy or combination aims to meet the needs of members of the organisation, through appropriate organisational behaviour (Mullins, 1999).

Weihrich and Koontz understand motivation as a general term that refers to a whole set of instincts, demands, needs, wishes and similar forces (Weihrich and Koontz, 1998). They see motivation as a chain reaction in which the needs that people have, lead to the wishes or goals, which ultimately leads to satisfaction. They also clearly indicate the difference between motivation and satisfaction, and in that context that motivation implies a desire for a result, while satisfaction is the consequence of that result (Weihrich and Koontz, 1998). Drever in his dictionary of psychology, very briefly defines motivation as a term which is mainly used for the appearance-related incentives, impulses and motives. Motive is defined as an affective-conative factor that participates in directing the individual's behaviour toward a goal, either knowingly, or unknowingly (Drever, 1964). Unlike Drever, Petz 
in psychological dictionary gives a wider explanation, and says that motivation is a state in which we are "from within" aroused by some needs, impulses, aspirations, desires or motives, and directed towards the achievement of a goal, which acts as an external behaviour stimulus (Petz, 1992). Motivation is a psychological category, and can be defined as encouraging employees to activity (Karavidić and Čukanović-Karavidić, 2010). All events in the business system as institutionalised organisation are manifestation of the work behaviour of the individual, which is further reflected through interaction in the form of group behaviour, and finally at the level of the business system summed up in the form of organisational behaviour (Bulat, 2008). Common to all definitions of work motivation is a set of incentives that influence employee satisfaction, and thus the direction, intensity and persistence of individual work efforts so that the aims and results of the organisation would be excellent.

\section{Employee satisfaction and work quality in schools}

Employee satisfaction is an integral part of the quality of work in schools because it depends on the attitudes of employees and their behaviour how they will conduct its business, which has a direct impact on the performance of the organisation as a whole. The leader knows that all employees want to evolve as a person through their work, to develop and use their talents and skills, to achieve results and success that will be recognised (Davis, 1992), where work does not just involve performing tasks but also active interaction with colleagues, other managers, respecting the rules and policies of the organisation, achieving standards of performance, etc. By the same author, satisfaction is defined as a positive emotional response and attitude of individuals towards their work, and it is a combination of internal and external factors. Internal factors include the nature of the work that a person performs, tasks which make a job, professional development, and a sense of responsibility and achievement at work, while external factors include working conditions, wages, collaboration with colleagues and managers, etc. Internal factors improve employee satisfaction and external factors prefer dissatisfaction (Sousa-Poza and Sousa-Poza, 2000).

Job satisfaction is considered to be the organisational outcome of school management which is also strongly correlated with the quality and student achievements. There are many references which indicate that correlation, and the importance of job satisfaction of teachers for school effectiveness. According to (Shann, 1998), teachers' job satisfaction is an extremely important factor influencing the commitment and performance of teachers and their retention in the profession. Also, the importance of job satisfaction of teachers for success in teaching and overall atmosphere of the school is evident and their job satisfaction comes through learning and progress (Hoerr, 2013). General satisfaction of pupils and overall satisfaction in school can hardly be achieved without teachers who are satisfied with their jobs (Wolk, 2008). Some authors suggest that despite some difficulties, the work of teachers brings numerous pleasures, and those pleasures are felt by most of the teachers (Eisner, 2006). There is a significant number of papers that deal with specific problems related to the satisfaction of teachers as organisational outcomes of school management, because this area is complex and depends on many influential values. For example, communication has an impact on teachers' job satisfaction (De Nobile and McCormick, 2008), effective communication affects job satisfaction (Kim, 2002). Working conditions and work environment have an impact on job satisfaction (Schonfeld, 2000). Workload impacts the satisfaction (Butt and Lance, 2005). The emotional intelligence of teachers affects job satisfaction as well (Wong et al., 2011). Summarising the above presentations into a single unit, it can be concluded that the job satisfaction of teachers is a very important area because it represents the organisational outcomes of school management which has a significant correlation with the other organisational outcomes that are of this work's interest, especially the quality and student outcomes (success in learning and behaviour).

\section{Organisational school culture}

For a better understanding of organisational (school) culture which includes values, beliefs and meanings that people attribute to their experiences at school, it should be known that the concept of school culture has its intellectual roots in sociology and anthropology, but its fundamentals are also drawn from the organisational culture as a management discipline. This connection is most easily observed from some definitions of organisational culture, such as it involves solid and widely accepted core values (O'Reilly, 1983), the way we do things around here (Deal and Kennedy, 1982), the collective mental program (Hofstede, 
1980), the common understanding (Van Mannen and Barley, 1983), the number of common, persistent beliefs that are transmitted through different symbolic media, creating meanings in the work lives of people (Kouzes et al., 1983).

That organisational culture has a strong influence on the organisation itself, regardless of its specificity as schools, is confirmed by Schein's definition of organisational culture which is actually a kind of collective interpretative scheme of organisation members due to which they similarly assign meanings to events, people, events in organisation and outside it, and refer to them in a similar manner (Schein, 2004). Character of the various components of management and organisations, such as strategy, structure, style of leadership, organisational learning, reward and motivation stems from the manner in which employees and managers understand the organisational reality and act in it (Wilderom et al., 2000). For a better understanding of the organisational culture in the context of school some principles are stated:

- Organisational culture is "ideology" of school.

- Organisational culture is the dominant pattern of behaviour of employees in teaching and nonteaching process.

- Organisational culture is a set of common beliefs and values of employees in school.

The process of development and the strength intensity of the organisational culture of the school as a single system will depend on the intensity of the adoption and application of these three principles through a process of individual behaviour of all stakeholders in the school system (student, teacher, principal).

\section{METODOLOGY RESEARCH SETTING}

\section{The function of management in education}

School management or management in education, is a relatively new scientific field that includes coordination of human, financial and material resources in the educational process, and in order to achieve the goals set forth in state, local and school education policy. It also includes managing the entire process of education, management of educational institution, management of teaching and non-teaching staff, and the organisation of the work process. Terminologically speaking, management in education is also the name of professional field, a scientific discipline, profession and function, and in this context it's possible to talk about it in broad terms (as the management and administration of the whole educational process, which is defined as an educational management), and in the narrow sense as management and leadership within the school (which implies the tasks of school principals, and is defined as the school management). Thus, the school management is a young discipline of school management as a non-profit organisation and is an integral part of a broader management in education.

The fact is that management occurs much later in education than in the economy, but in some other areas as well, and the reason for that is, above all, its specific social position. Namely, in all countries of the region, the educational process has until recently been completely centrally controlled (free market principles), where the role of the school manager (principal) was to implement transfer decisions made at the state level. Recently, this relationship is significantly changing, with increasingly present decentralisation and greater autonomy of decision-making, more responsibility is increasingly transferred at lower levels. In this new context school principals are required to make independent decisions in the interest of the school as a business system and pupils as end users of the school process, and to care for the timely and efficient implementation of these decisions.

However, according to most empirical researches on competence model of school principals conducted in the countries of the region, school principals as creators and holders of most school management activities were rated as average, IT incompetent, inefficient and very weak in motivating their employees to work (Staničić, 2002). Also, the practice of schools that were the subject of research during the writing of this paper, shows that the school management still relies on outdated (non-market) centralised management model, making it unsuccessful, dormant and lacking imagination (Drucker, 1994). To change this situation for the better, professionalization that will allow proper and systematic training of future school principals is necessary, since one of the key problems in this area is that the position of school principals is still not viewed as a profession, but as a function (Staničić, 2006). On the other hand, the essence of management in education is reflected in the four key functions: management, leadership, management of the staff and school as an organisation (Staničić, 2006), as shown in Figure 1. 
Management includes harmonisation of financial, administrative, human and time resources in the school system.

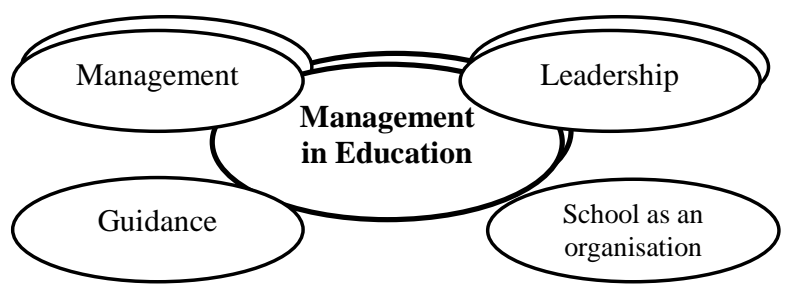

Figure 1: The functions of management in education (Source: Staničić, 2006.)

Leadership is the executive function within the educational management, and it includes personal organisational skills, communication skills, time management, and other management skills, and as such it actually represents a key activity for the alignment of all available potentials for optimal realisation of the goals of school.

Guidance and human resource management as a basic development potential in school management, is one of the key processes for which this area will be specially treated in the sequel. Specifically, neglect of employees (which in practice is very often the case), low level of motivation to work, poor quality services, poor working environment, inadequate knowledge management, ineffective teamwork, dissatisfaction of employees and its consequences like poor leadership, are just some of the difficulties that are characteristic of all non-profit organisations as well as of school.

School organisation is the fourth and also the essential function of school management, and has a significant correlation with all present trends of decentralisation of school and the need for professionalism and management education of school principals. Namely, practice has shown that centralised (outdated) approach to school organisation hinders the development of school management, while on the other hand, the practice of school decentralisation (high autonomy), allows much better business and better organisational outcomes, because in such a system management is actually assigned to managers.

\section{The advantage of leadership guidance in relation to school management}

The concept of guidance in literature is defined in different ways and with different approaches, but they all essentially emphasise that the guidance is a process of impact that helps a group of individuals to achieve their common goal. For clarity of understanding, it is important to note the difference between concepts of management and guidance, because management primarily (in simple terms) wants to ensure that the organisation operates stably and orderly, and therefore management is focused on the structure of the organisation, while on the other hand guidance involves a process that includes working with people and achieving goals and its primary function is to initiate structural changes in the organisation, which is why most authors agree that guidance keeps focused on the idea. Experience has shown that organisations that have expressed (strong) management and do not have guidance or it is weak, eventually become slow, sluggish and emphasised bureaucratic, while on the other side, organisations that have expressed (more) guidance from management, can easily fall into the change process without a clear strategy, which is why the development and progress of any organisation including school as a specific business organisations alike need both of these processes.

Figure2. shows the scheme of management personnel in 23 secondary schools where the research was made to investigate the influence of leadership on organisational outcomes, with special emphasis on student achievement (success in learning and behaviour) as a key outcome specific to the educational process, the job satisfaction, the quality of the school and the school (organisational) culture.

Keeping the school includes a presentation of objectives and tasks to employees, pointing to possible solutions and ways of realisation, harmonisation of employees' efforts to achieve program tasks, creating an atmosphere of cooperation, security and internal harmony, the stimulus to increased activity and creative approach to work, communication development, fostering professional development, representing the interests of employees in front of other subjects of life and school work (Staničić, 2006). Guidance in school is influenced by various factors, such as school size (number of teachers, pupils and classes), type of school (elementary school, high schools, vocational schools, public or private school), the location of the school (large city, small town, town, village), socioeconomic factors (economic development), parental involvement in school decision-making, experience and motivation for the work of teachers and nonteaching staff, school (organisational) culture, etc. 


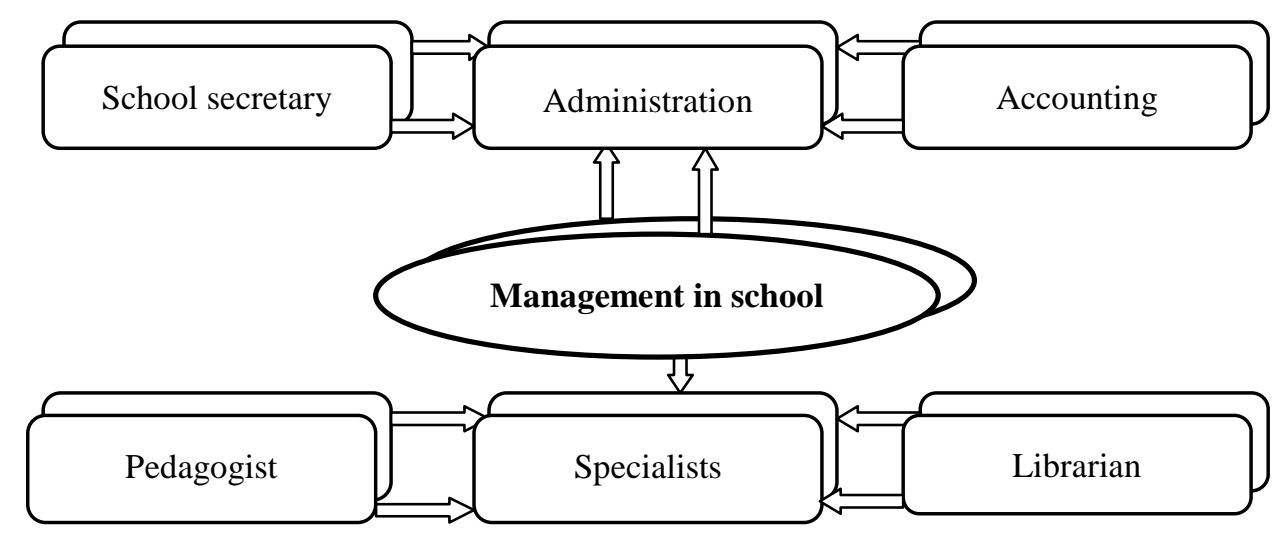

Figure2: The structure of school management in schools in the Una-Sana Canton (Source: Authors)

In the countries of the region laws have defined school principals as business and professional (pedagogical) personalities that lead the school, and who have the task to lead the school as a business organisation, and to motivate their employees to achieve the best possible results so the final outcome of their work (student achievement) would be at the higher level. In accomplishing these tasks, the principals should have some management and leadership skills and knowledge to be able to perceive and analyse the specific situation of the school, in order to perceive the needs of their employees, and ultimately to select the appropriate style or model of leadership. The quality of leadership and hence the quality of organisational outcomes affects the type of model that the school principal prefers in his work.

Insight into the theories and models of educational management shows that it is clear there is no uniform approach regarding the functioning of educational institutions, and because of differences in school there are different models of leadership. Cuthbert (1984) summarises the models into five groups, which are: analytical and rational, pragmatic rational, political, phenomenological and interactive. He takes levels and intensities of agreement among employees about their goals, ways to evaluate the effectiveness of the structure concept of the institution (organisation) as criteria for the design. Bolman and Deal (1984) give four views or frames: structural, human resource, political and symbolic. Morgan (1997) offers the metaphor of organisations and appoints them as: mechanical, organic, thoughtful, cultural and political. Integration of the above views of the models was done by Tony Bush (2003), the English theorist of management and leadership in education, who bases the distinction between theory and model on the objectives, structure, environment and leadership in educational organisations, and stressed the importance and priority of organisational goals in relation to the individual goals of employees, and in that context established six models of management in educational organisations: formal, collegial, political, subjective, ambiguous and culturally. These models are linked with appropriate models of leadership (Bush, 2003):

- Managerial (Principal is the extended arm of the educational authorities).

- Instructional (Principal is also a pedagogue teaching the teachers in their work).

- Participatory (Teacher participates in decisionmaking).

- Transaction (Principal rewards commitment).

- Postmodern (Principal relies on individuals rather than on teams).

- Situational (Principal adapts leadership style to the situation).

- Moral (Principal holds on ethical principles).

- Transformational (Principal relies on people); it is the preferred model, which affects the quality of school management as a specific business organisation.

The share of individual models in educational institutions depends on their size, organisational structure, the amount of time allocated to the management, of available resources and environment institutions (Bush, 2003).

Modern understanding of good leadership points out the concern for human resources (human resource management), because it is just the potential which contributes to increased organisational and job quality, as in all areas, including the field of education. Such development of a fact has determined the desirable profile of a good principal who should be a leader more than a manager. Management and leadership in everyday speech are often used interchangeably. However, 
there is a clear difference between these two terms. As a basic criterion in their delimitation, there is just attitude towards people and their values. Management is mainly associated with the occurrence of the organisational aspect of the business operations system (in our case, schools), such as: planning, analysing, organising, financing, monitoring, etc., while leadership or guidance is linked to people, their behaviour, work style, communication, motivation. Thus, the manager maintains systems, relies on control, monitors things in the short term, accepting the status quo, while leader with leadership competencies motivates, encourages, gives positive energy, observes things in the long term, has the vision, challenges and changes the status quo (Middlehurst and Elton, 1992). Essentially:

- Management is carried out over the property and guidance over the people.

- The function of management is to provide jobs and to control their implementation, and of leadership, to explain the direction of change and the soliciting organisation members to participate in the process of change.

- Leadership means having a vision of what a business organisation (school) is and what it can become, but also the ability of directing others to accept this vision.

- While managers are rational, leaders are emotional. (Fenton, 1990)

- The manager uses formal procedures and rational methods, while leader launches emotions and inflames passions.

- Management and leadership are different, but both are important, because the business system such as school requires a modern organisation that involves the full reality of management and wise conduct of the leaders' vision. (Bolman and Deal, 1984)

Figure 3 shows the correlation between management and leadership in terms of emotion and reason.

Leadership means having a vision of what institution is and what it can become, but also the ability of others to accept this vision (Kovač, 2004). Unfortunately, despite of all the above, as well as the obvious need for the appointment of school principals who have expressed a particular management leadership competencies, leading to a significantly more efficient school management as well as business profit organisations with specific educational process, practice in schools that were surveyed during the writing of this paper, shows that the teachers who have worked in school previous years, and who have no or little managerial knowledge are generally set for school principals. In addition, for the good governance of the school, commitment and enthusiasm towards children in general and to the school that educates them are important, and then, the persistence in developing interpersonal communication skills through which the good principal will create a sense of trust with teachers and pupils, but also with his vision and enthusiasm carry out the directing of all school processes in the desired (positive) direction, which will, for pupils and teachers, result with a sense of empowerment of environment that supports them. This mode results in constant improvement of all organisational outcomes in school, primarily a few of the key outcomes that actually constitute the primary object of the educational process: quality of the educational process, high student achievement (success in learning and behaviour), job satisfaction, school (organisational) culture, motivation for work. A good manager should first of all know what is not the area of school management quality: management control, an instrument of punishment or reward, there is no management role, and that the quality is not the duty of authority for quality assurance, nor any single body or individual, but all together. Key indicators of the school quality are teachers with their individual and professional traits:

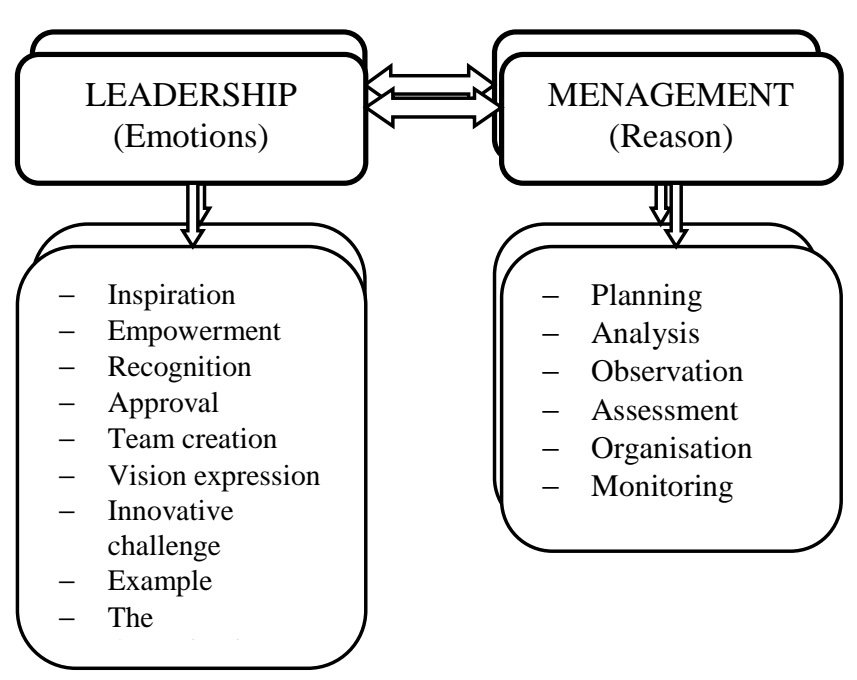

Figure 3: Correlation between management and leadership with aspect of emotion and reason (Source: Fenton, 1990)

- General culture and personality traits: stability, communication, motivation, correctness, fairness, objectivity, consistency.

- Relationship to the pupils: influence mood, respect, empathy, cooperation, cooperation and assistance; 
- Creativity: improving, raising quality, contribution to the development, scientific and professional competence.

- Teaching skills and techniques: competence, knowledge of materials, exposure of substances, use of resources.

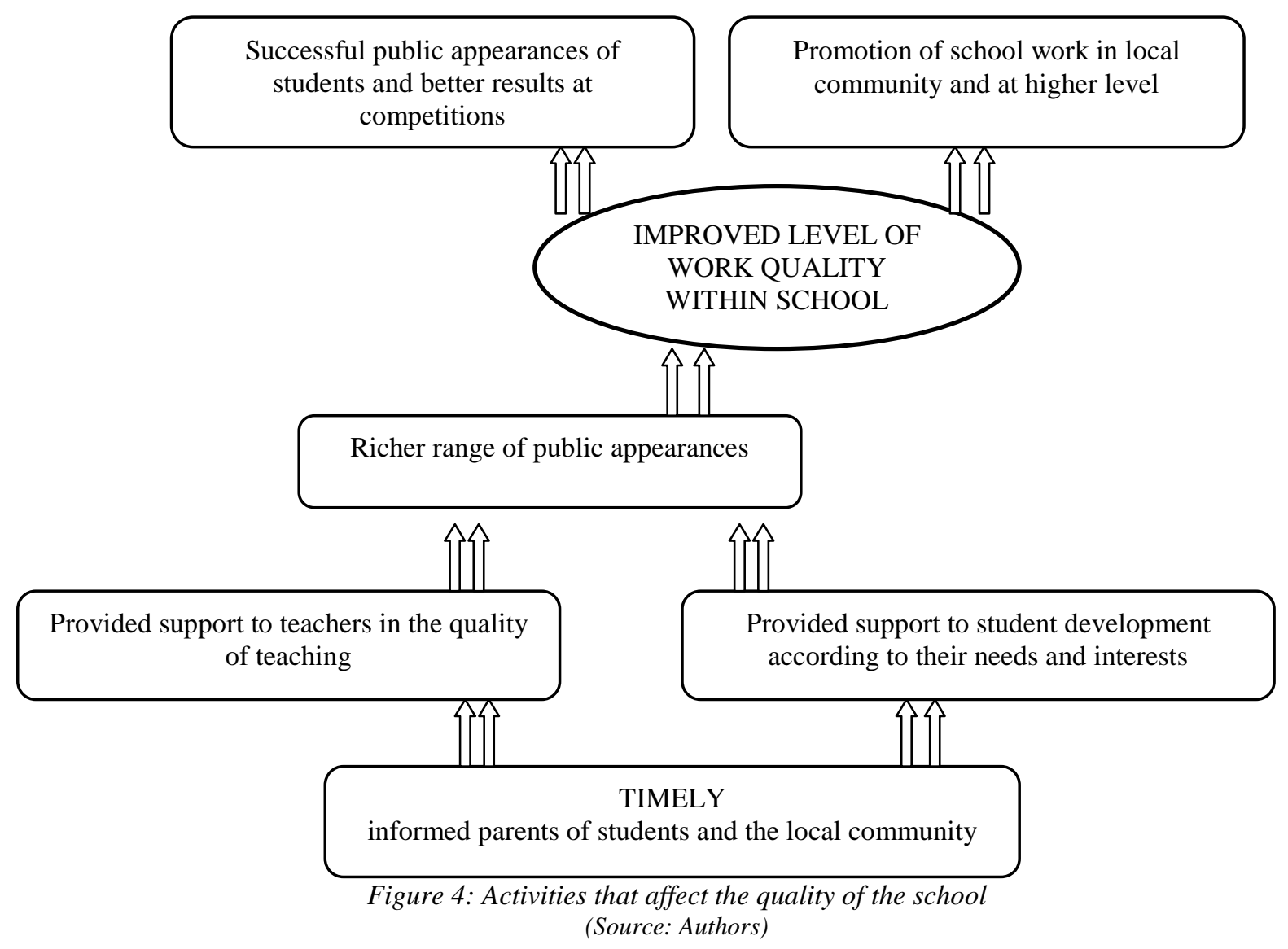

Objectives, tasks and hypothesis of the research

The main objective of this study was to determine the extent to which pupils of the school run by the principal with the leadership competencies who prefers the role of the leader conduct in relation to the classical management control, have better outcomes in learning and behaviour of those pupils who attend the school whose principal has no leadership competencies and prefers management control more than a leadership conduct. Also, the goal was, by comparison of pupils' success in learning and behaviour in schools, to compare the quality of school climate that is different from school to school as the result of varying quality of organisational outcomes and performances which are mentioned in the paper. Thus, different outcomes indicate the diversity of the school atmosphere and the quality of organisational outcomes.
Figure 4 shows the school activities which in the opinion of the author can significantly improve the quality of school work.
Provided support to student development

The main task of the research was that on the basis of student achievement and other indicators of the holders of school activities (principal and teacher), collected using interviews and instrument in the form of a questionnaire, to determine in which schools are the organisational outcomes listed lower than the cantonal average, so that in these schools should be, in recent time, organized an advisory supervision over the work of school management and teachers, in order to realise additional education in "critical" schools and thus trying to improve school performance and outcomes, with special emphasis on student success as the primary outcome of the educational process in secondary schools.

\section{Hypothesis of the research}

Schools whose principals have a role of the leader, have better results in terms of improving organisational performance and outcomes, particularly student achievement (success), 
compared to the school principals who manage schools the classic management way.

\section{The method and mode of work}

The study was carried out in 23 secondary schools in Una-Sana Canton, upon completion of the first term of the academic 2013/14 year (March, April and May 2014). The survey was preceded by an introductory explanation to principals, professional associates and teachers about the purpose and significance of the research, followed by an explanation that their participation is voluntary and that they were guaranteed anonymity and confidentiality of the data that will be used only for scientific research purposes. The interest of the interviewed teachers and school principals was great which is why a large number of questions have an answer, and only a few remained unanswered. Completing the questionnaire required approximately 15 minutes and a conversation lasted an additional 15 minutes. To conduct the research a method of scientific research has been used, as well as a survey and interviewing techniques, and an instrument in the form of questionnaires. The survey is anonymous and the questionnaire consisted of 20 questions with three possible answers on the extent and intensity of organisational performance: small, average, large. Questions included the 5 areas: leader behaviour, the quality of the school, job satisfaction, work motivation, organisational (school) culture. The research sample included 23 principals and 50 teachers. The main objective was to determine the influence of leadership, or leadership competencies of school principals on key organisational school outcomes, the results (success) in learning and behaviour of pupils, but also on other outcomes that are correlated with success, such as the quality of the school and job satisfaction.

\section{RESEARCH RESULTS}

The questions from the survey and the interview in the context of research objectives and content of this work were compiled to determine the role of a principal of schools and his/ her role as a the part of employees:

1. The scope and intensity of leadership behaviour of school principals.

2. The scope and intensity of quality in school.

3. The scope and intensity of job satisfaction.

4. The scope and intensity of motivation to work.

5. The scope and intensity of school culture.

The results of the research and answers to these questions are shown in Figure 5.

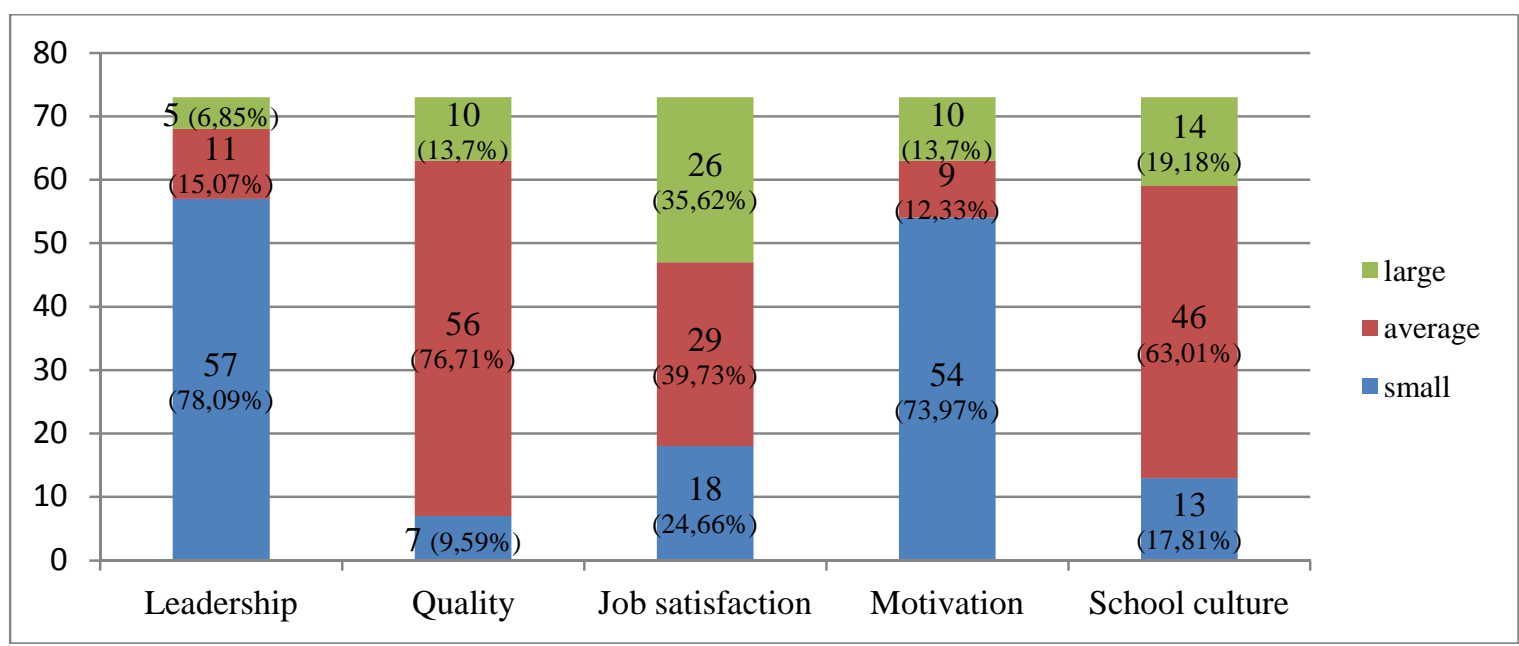

Figure 5: Results of leadership research, relationship quality, job satisfaction, motivation, school culture

Table 1 shows the results of the success of high school pupils in Una-Sana Canton in learning at the end of the first term of the academic 2013-14 year.
Table 2 presents the results of high school pupils in Una-Sana Canton in behaviour at the end of the first term of the academic 2013/14 year. 
Table 1: Success of pupils in learning at the end of the first term of the academic 2013-14 year

\begin{tabular}{|c|c|c|c|c|c|c|c|c|c|c|c|c|}
\hline \multirow{2}{*}{ SCHOOL } & \multirow{2}{*}{$\begin{array}{c}\text { NUMBER OF } \\
\text { PUPILS } \\
\Sigma \\
\end{array}$} & \multicolumn{6}{|c|}{ POSITIVE MARK } & \multicolumn{2}{|c|}{$\begin{array}{c}\text { NEGATIVE } \\
\text { (1) }\end{array}$} & \multicolumn{2}{|c|}{ UNMARKED } & \multirow{2}{*}{ AVERAGE } \\
\hline & & $(5)$ & (4) & (3) & $(2)$ & $\Sigma$ & $\%$ & $\Sigma$ & $\%$ & $\Sigma$ & $\%$ & \\
\hline \begin{tabular}{|l|} 
Grammar school \\
\end{tabular} & 676 & 141 & 238 & 115 & 1 & 495 & 73.22 & 177 & 26.18 & 4 & 0.59 & 3.25 \\
\hline Machine-traffic school & 626 & 35 & 152 & 231 & 7 & 425 & 67.89 & 174 & 27.80 & 27 & 4.31 & 2.78 \\
\hline Medical School & 700 & 104 & 195 & 105 & 0 & 404 & 57.71 & 294 & 42.00 & 2 & 0.29 & 2.73 \\
\hline \begin{tabular}{|l|} 
School of Economics \\
\end{tabular} & 686 & 51 & 210 & 109 & 0 & 370 & 53.94 & 313 & 45.63 & 3 & 0.44 & 2.54 \\
\hline School of Electrical Engineering & 400 & 38 & 101 & 137 & 10 & 286 & 71.50 & 110 & 27.50 & 4 & 1.00 & 2.87 \\
\hline Art School & 104 & 19 & 33 & 15 & 0 & 67 & 64.42 & 37 & 35.58 & 0 & 0.00 & 2.97 \\
\hline \begin{tabular}{|l} 
Una Sana College \\
\end{tabular} & 235 & 126 & 83 & 14 & 1 & 224 & 95.32 & 11 & 4.68 & 0 & 0.00 & 4.33 \\
\hline Catholic school centre & 111 & 17 & 25 & 17 & 0 & 59 & 53.15 & 52 & 46.85 & 0 & 0.00 & 2.59 \\
\hline BIHAĆ & 3538 & 531 & 1037 & 743 & 19 & 2330 & 65.86 & 1168 & 33.01 & 40 & 1.13 & 2.93 \\
\hline \begin{tabular}{|l|} 
Grammar school \\
\end{tabular} & 380 & 73 & 136 & 64 & 0 & 273 & 71.84 & 104 & 27.37 & 3 & 0.79 & 3.20 \\
\hline Mixed Secondary School & 673 & 13 & 138 & 190 & 7 & 348 & 51.71 & 314 & 46.66 & 11 & 1.63 & 2.29 \\
\hline BOSANSKA KRUPA & 1053 & 86 & 274 & 254 & 7 & 621 & 58.97 & 418 & 39.70 & 14 & $\mathbf{1 . 3 3}$ & 3.15 \\
\hline \begin{tabular}{|l|} 
Mixed Secondary School \\
\end{tabular} & 271 & 34 & 69 & 80 & 2 & 185 & 68.27 & 86 & 31.73 & 0 & 0.00 & 2.86 \\
\hline BOSANSKI PETROVAC & 271 & 34 & 69 & 80 & 2 & 185 & 68.27 & 86 & 31.73 & $\mathbf{0}$ & $\mathbf{0 . 0 0}$ & 2.86 \\
\hline Mixed Secondary School & 749 & 44 & 146 & 203 & 38 & 431 & 57.54 & 316 & 42.19 & 2 & 0.27 & 2.42 \\
\hline BUŽIM & 749 & 44 & 146 & 203 & 38 & 431 & 57.54 & 316 & 42.19 & 2 & 0.27 & 2.42 \\
\hline Grammar school & 482 & 96 & 169 & 98 & 1 & 364 & 75.52 & 112 & 23.24 & 6 & 1.24 & 3.29 \\
\hline I High School & 907 & 43 & 179 & 256 & 20 & 498 & 54.91 & 408 & 44.98 & 1 & 0.11 & 2.37 \\
\hline II High School & 882 & 70 & 220 & 218 & 8 & 516 & 58.50 & 363 & 41.16 & 3 & 0.34 & 2.57 \\
\hline Islamic High School & 292 & 62 & 73 & 57 & 4 & 196 & 67.12 & 96 & 32.88 & 0 & 0.00 & 3.00 \\
\hline CAZIN & 2563 & 271 & 641 & 629 & 33 & 1574 & 61.41 & 979 & 38.20 & 10 & 0.39 & 2.68 \\
\hline Mixed Secondary School & 568 & 43 & 141 & 130 & 4 & 318 & 55.99 & 246 & 43.31 & 4 & 0.70 & 2.52 \\
\hline KLJUČ & 568 & 43 & 141 & 130 & 4 & 318 & 55.99 & 246 & 43.31 & 4 & 0.70 & 2.52 \\
\hline Grammar school & 329 & 96 & 129 & 34 & 1 & 260 & 79.03 & 69 & 20.97 & 0 & 0.00 & 3.55 \\
\hline Mixed Secondary School & 836 & 56 & 166 & 150 & 2 & 374 & 44.74 & 462 & 55.26 & 0 & 0.00 & 2.22 \\
\hline Agricultural School & 250 & 34 & 65 & 21 & 0 & 120 & 48.00 & 130 & 52.00 & 0 & 0.00 & 2.49 \\
\hline \begin{tabular}{|l|} 
SANSKI MOST \\
\end{tabular} & 1415 & 186 & 360 & 205 & 3 & 754 & 53.29 & 661 & 46.71 & $\mathbf{0}$ & $\mathbf{0 . 0 0}$ & 2.58 \\
\hline Grammar school & 288 & 49 & 67 & 72 & 0 & 188 & 65.28 & 100 & 34.72 & 0 & 0.00 & 2.88 \\
\hline I High School & 569 & 26 & 107 & 200 & 18 & 351 & 61.69 & 218 & 38.31 & 0 & 0.00 & 2.48 \\
\hline II High School & 789 & 57 & 207 & 260 & 13 & 537 & 68.06 & 252 & 31.94 & 0 & 0.00 & 2.75 \\
\hline \begin{tabular}{|l} 
VELIKA KLADUŠA \\
\end{tabular} & 1646 & 132 & 381 & $\mathbf{5 3 2}$ & 31 & 1076 & 65.37 & 570 & 34.63 & $\mathbf{0}$ & $\mathbf{0 . 0 0}$ & 2.68 \\
\hline \begin{tabular}{|l} 
UNA-SANA CANTON \\
\end{tabular} & 11803 & 1327 & 3049 & 2776 & 137 & 7289 & 61.76 & 4444 & 37.65 & 70 & 0.59 & 2.72 \\
\hline
\end{tabular}

Table 2: Success of pupils in behaviour at the end of the first term of the academic 2013-14 year

\begin{tabular}{|c|c|c|c|c|c|c|c|c|c|c|c|c|}
\hline \multirow{3}{*}{ SCHOOL } & \multirow{3}{*}{$\begin{array}{c}\text { NUMBER } \\
\text { OF PUPILS } \\
\Sigma\end{array}$} & \multirow{3}{*}{ (5) } & \multirow{3}{*}{ (4) } & \multirow{3}{*}{ (3) } & \multirow{3}{*}{ (2) } & \multirow{3}{*}{ (1) } & \multirow{3}{*}{ 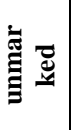 } & \multicolumn{5}{|c|}{ ABSENCES } \\
\hline & & & & & & & & $\mathbf{O}$ & $\mathbf{N}$ & $\Sigma$ & averag & pupil \\
\hline & & & & & & & & & & 2 & E & $\mathbf{U}$ \\
\hline Grammar school & 676 & \begin{tabular}{l|l|}
479 \\
\end{tabular} & 117 & 52 & 19 & 9 & 0 & 14617 & 2278 & 16895 & 22 & 3 \\
\hline Machine-traffic school & 626 & 348 & 134 & 71 & 35 & 37 & 1 & 12803 & 4410 & 17213 & 20 & 7 \\
\hline Medical School & 700 & 544 & 88 & 49 & 15 & 4 & 0 & 7716 & 1880 & 9596 & 11 & 3 \\
\hline School of Economics & 686 & 471 & 45 & 73 & 49 & 48 & 0 & 9801 & 4725 & 14526 & 14 & \\
\hline School of Electrical Engineering & 400 & 213 & 77 & 53 & 10 & 47 & 0 & 8256 & 2664 & 10920 & 21 & 7 \\
\hline Art School & 104 & 75 & 12 & 5 & 7 & 5 & 0 & 2371 & 415 & 2786 & 23 & 4 \\
\hline Una Sana College & 235 & 205 & 16 & 12 & 2 & 0 & 0 & 6103 & 736 & 6839 & 26 & 3 \\
\hline Catholic school centre & 111 & 95 & 15 & 0 & 0 & 1 & 0 & 1628 & 141 & 1769 & 15 & \\
\hline BIHAĆ & 3538 & 2430 & 504 & 315 & 137 & 151 & 1 & 63295 & 17249 & \begin{tabular}{|l|l|l|}
80544 & \\
\end{tabular} & 18 & 5 \\
\hline Grammar school & 380 & 327 & 44 & 6 & 0 & 0 & 3 & 6661 & 602 & 7263 & 18 & \\
\hline Mixed Secondary School & 673 & 389 & 93 & 86 & 43 & 61 & 1 & 10917 & 6091 & 17008 & 16 & 9 \\
\hline BOSANSKA KRUPA & 1053 & 716 & 137 & 92 & 43 & 61 & 4 & 17578 & 6693 & 24271 & 17 & 6 \\
\hline Mixed & 271 & 193 & 43 & 19 & 8 & 8 & 0 & 3551 & 838 & 4389 & 13 & 3 \\
\hline BOSANSKI PETROVAC & 271 & 193 & 43 & 19 & $\mathbf{8}$ & 8 & $\mathbf{0}$ & 3551 & 838 & 4389 & 13 & 3 \\
\hline Mixed Secondary School & 749 & 536 & 103 & 60 & 29 & 21 & 0 & 11075 & 3668 & 14743 & 15 & 5 \\
\hline BUŽIM & 749 & 536 & 103 & 60 & 29 & 21 & $\mathbf{0}$ & 11075 & 3668 & 14743 & 15 & 5 \\
\hline Grammar school & 482 & 427 & 18 & 26 & 11 & 0 & 0 & 7415 & 1281 & 8696 & 15 & 3 \\
\hline I High School & 907 & 569 & 165 & 100 & 58 & 15 & 0 & 9513 & 4085 & 13598 & 10 & 5 \\
\hline II High School & 882 & 692 & 112 & 54 & 20 & 4 & 0 & 12578 & 2777 & 15355 & 14 & 3 \\
\hline \begin{tabular}{|l} 
Islamic High School \\
\end{tabular} & 292 & 255 & 14 & 5 & 4 & 14 & 0 & 3336 & 455 & 3791 & 11 & 2 \\
\hline CAZIN & 2563 & 1943 & 309 & \begin{tabular}{|c|}
185 \\
\end{tabular} & 93 & 33 & 0 & 32842 & 8598 & 41440 & 13 & 3 \\
\hline Mixed Secondary School & 568 & 437 & 24 & 44 & 24 & 39 & 0 & 11505 & 2775 & 14280 & 20 & 5 \\
\hline KLJUČ & 568 & 437 & 24 & 44 & 24 & 39 & $\mathbf{0}$ & 11505 & 2775 & 14280 & 20 & 5 \\
\hline Grammar school & 329 & 303 & 16 & 10 & 0 & 0 & 0 & 5432 & 734 & 6166 & 17 & 2 \\
\hline Mixed Secondary School & 836 & 606 & 98 & 70 & 25 & 37 & 0 & 15156 & 4611 & 19767 & 18 & $\frac{2}{6}$ \\
\hline Agricultural School & 250 & 201 & 19 & 25 & 4 & 1 & 0 & 4876 & 1295 & 6171 & 20 & 5 \\
\hline SA & 1415 & 1110 & 133 & 105 & 29 & 38 & $\mathbf{0}$ & 25464 & 6640 & 32104 & 18 & 5 \\
\hline Grammat & 288 & 235 & 34 & 16 & 3 & 0 & 0 & 4953 & 637 & 5590 & 17 & 2 \\
\hline I High School & 569 & 353 & 60 & 81 & 52 & 23 & 0 & 8134 & 3793 & 11927 & 14 & 7 \\
\hline II High School & 789 & 690 & 59 & 23 & 9 & 8 & 0 & 6748 & 1529 & 8277 & 9 & 2 \\
\hline VEI & 164 & 1278 & & 120 & 64 & 31 & 0 & 19835 & 5959 & 25794 & 12 & 4 \\
\hline UNA-SANA CANTON & 11803 & 8643 & 1406 & 940 & 427 & 382 & 5 & 185145 & 52420 & 237565 & 16 & 4 \\
\hline
\end{tabular}


Practice of advisory supervision over the work of management and school teachers, who are conducted by advisers of Pedagogical Institute, showed that the main indicator of "condition" in a school, in all elements, is the outcome of learning and behaviour that pupils in a school achieve during one term. By measuring these outcomes the way it has been done in the preceding tables, it creates a good basis for deeper analysis of other organisational performance. Specifically, if the average score at the level of a school is under the cantonal average and the number of absences of pupils and schools is above average at the cantonal level, it is the first measurable indicator that suggests that the "situation" at the school, in terms of its organisational performance, is not satisfactory, and that the "deeper" analysis should determine the state of each performance individually. As a concrete example of the above propositions is Medical school, only in the canton, which is normally recorded and attended by the best elementary school pupils from all eight municipalities, and during the relevant measuring of their success in learning it was found that the average grade at the school is 2,73 . This indicator suggests that the success of pupils in relation to the input success is relatively low (e.g. less than Mechanical Engineering School, where the average score is 2.78 and the input average is significantly lower than the Medical School), and that in that school organisational outcomes that affect the total school environment that creates student success (motivation, job satisfaction, quality, school culture), are not at a satisfactory level, which suggests that the school management has not created a good motivational atmosphere that would result in higher satisfaction of employees, and that it would impact on improving the school culture and the quality of the teacher.

Therefore, the need of the specified measurements presented in the tables and in the diagram, is reflected in the fact that student achievement is a good indicator of the quality of organisational performance and outcomes of a school, and at the same time, it is a guidance to the responsible authorities in what direction theye should act. This action involves maintaining professional consulting, training and workshops where management and teachers familiarise themselves with knowledge and skills that will help them improve their organisational outcomes, while improving school atmosphere, which eventually results in the improvement of student achievement as a key outcome of the educational process.

\section{DISCUSSION}

The research has shown that in schools there is a certain intensity of management and other employees to strengthen some indicators (outcomes), a slight increase in motivation and school culture in relation to leadership, quality and job satisfaction. As an example, leadership competencies are highlighted, namely Figure 5 shows that of the 73 respondents, only $5(6.85 \%)$ possessed a "large" scale and intensity of leadership competences, 11 of them (15.07\%) "partially" have the leadership competences and even 57 of them $(78.09 \%)$ have no leadership competences. The first 5 are principals of Una Sana College and two teachers from that school, and it is a school that had the highest mean (average) score 4.33 in the first term. Opposite to them, 57 respondents who have no leadership competencies, knowledge and skills, are mostly principals and teachers of schools that have a low average. There is a similar situation with other outcomes shown in the chart, because schools that have better student achievement, also have greater percentage of the volume and intensity of quality, job satisfaction, motivation and school culture, and where the outcome of the pupils is lower, the scope and the intensity of the above outcomes are lower as well. Another indicator of relatively low volume and intensity of organisational outcomes and school performance (included by this measure), is a large number of pupils' absences from school. Analyses of pupils' behaviour in general terms regarding student attitude towards school work, relationship with the teacher and classmates, as well as the entirety of the school ethos, shows that in fact the regularity of the presence of pupils in the teaching process is not great. The data that were obtained through the measurement and analysis indicate the unacceptability and concern over the emergence of a huge number of absences of pupils from the educational process, and this shows commitment that this phenomenon should be investigated and analysed more seriously and responsibly by all segments of society. These absences are directly related to the results of the educational process and other organisational outcomes of school as organisation-specific social responsibility. As an example we cite Machinetraffic school Bihać, which has 17,213 absences or 27 per student, while the II High School in Velika Kladuša has only 11 absences per student. As another example, we cite the Agricultural School in Sanski Most, which has boarding accommodation for their pupils because it is the only one in Canton, but despite of boarding the 
number of pupils' absence from school is a serious concern ( 25 per student). The total number of absences at the cantonal level for 11,803 pupils was 237,656 , or 20 per student, which is disturbing. In the context of the above, the study results showed the necessity of organised activities of educational authorities to train school management for adequate involvement in creating a positive school atmosphere as a precondition for strengthening organisational outcomes, primarily to achieve a higher level of school quality. The research leads to the conclusion that the existing practice of uncoordinated actions of school principals as a chief school manager is insufficient to achieve better results.

Also, the research shows that there are statically significant correlation dimensions of leadership with the dimensions of work motivation, job satisfaction, quality and school culture, which ultimately results in the success of pupils in learning and behaviour as the most important outcome of the educational process. The study results suggest that some of the surveyed principals apply known methods, so that the quality of their work and organisational performance would be increased to a higher level. Commendable is the fact that a number of respondents expressed a desire to adopt a leadership competencies to help them in their job to "step into the future" easier, and create a vision of their work and functioning of schools in some future time.

In line with the hypothesis, the results indicate that schools which are guided with leadership have better results and organisational outcomes of schools that have management control. Finally it should be noted that the sample for this study was small (23 schools in eight municipalities), but the results are interesting, which is why it would be good to repeat similar research on a larger sample to obtain a more objective picture.

\section{CONCLUSION}

In reality, the great leaders act through emotions and they actually act as emotional guides of employees in the organisation. To implement the vision, leaders motivate, direct, inspire, listen, persuade. It is important to know that emotions that are prevalent in people at work most directly reflect the quality of work life. The percentage of time in which people experience positive emotions at work is very large, and in this sense, managers who spread negative rather than positive energy, are simply bad for the organisation. Motivation, job satisfaction, school culture and quality have become key issues of modern school management organisation, and it is important that school principals should adopt and apply leadership skills and knowledge in order to effect significantly positive on the performance in their school. On the other hand, the school culture should implement a system of measurement and development of quality, motivation and satisfaction of employees, in order to give each individual a feeling that they share a common destiny of organisation (school), which would encourage to act on the release of creative and originate potential, which of course contributes to better organisational outcomes. This research had a task to determine in which schools are listed organisational outcomes lower than the cantonal average, to recently organise an advisory supervision in those schools over the work of the school management and teachers, and to realise additional education in those "critical" schools and so try to improve school performance and outcomes, with special emphasis on student success as the primary outcome of the educational process in secondary schools.

Thus, the research results have identified schools where educational institutions are responsible for supervision of the school as those which should immediately act and provide advisory assistance to the management of these schools to improve organisational outcomes. The same research will be repeated in order to determine whether there was any improvement of outcomes.

The school principals as the main coordinators of this process, in accordance with their professional competence (which is different from the principal to the principal), nevertheless carry out certain activities in the direction of change and awareness. In order to be effective, school principals should pay attention to development of their leadership competences which can be achieved by attending relevant seminars, workshops and courses in the field of leadership and management in schools.

\section{REFERENCES}

Bass, B. M. (1981). Stogdill's Handbook of Leadership: A Survey of Theory and Research. New York: The Free Press.

Bennis, W., \& Nanus, B. (1985). Leadership: The strategies for taking charge. New York: Harper \& Row.

Bolman, L. G., \& Deal, T. E. (1984). Modern Approaches to Understanding and Managing Organisations. San Francisco, CA: Jossey-Bass. Buble, M. (2010). Menadžerske vještine. Zagreb: 
Sinergija nakladništvo.

Bulat, V. (2008). Menadžment. Kruševac: ICIM plus.

Bush, T. (2003). Theories of Educational Leadership and Menagement (3rd ed.). London: SAGE Publications.

Butt, G., \& Lance, A. (2005). Secondary teacher workload and job satisfaction: Do successful strategies for change exist? Educational Management Administration \& Leadership, 33(4), 401-422.

Collins, J. (2007). Od dobrog do izvrsnog. Zagreb: Binoza press.

Cuthbert, R. (1984). The Management Process, E324 Management in Post Compulsory Education. Buckingham: Open University Press.

Davis, R. V. (1992). Job satisfacion. In L. K. Jones (Ed.), Encyclopaedia of career change and work issues (pp. 142-143). Phoenix: The Oryx press.

De Nobile, J. J., \& MeCommick, J. (2008). Organisational Communication and Job Satisfaction in Australian Catholic Primary Schools. Educational Management Administration \& Leadership, 36(1), 101-122.

Deal, T. E., \& Kennedy, A. A. (1982). Corporate Cultures. Reading, MA: Addison - Wesley.

Drever, J. (1964). A dictionary of psychology. Baltimore: Penguin Books.

Drucker, P. (1994). Nova zbilja. Zagreb: Novi lider.

Eisner, E. (2006). The Satisfactions of Teaching. Educational leadership, 63(6), 44-46.

Fenton, J. (1990). 101 Ways to Boost Your Business Performance. Mandarin Business: New York.

Gardner, H. (1996). Leading Minds - An Anatomy of Leadership. New York: BasicBooks.

Hoerr, T. R. (2013). Principal connection: Is your school happy? Educational leadership, 70(8), 86-87.

Hofstede, G. (1980). Culture's Consequences: International Differences in Work - related Values. Beverly Hills, CA: Sage Publications.

Howell, J. P., \& Costley, D. L. (2001). Understanding Behaviors For Effective Leadership. New Jersey: Prentice Hall.

Karavidić, S., \& Čukanović-Karavidić, M. (2010). Menadžment. Beograd: Visoka škola za poslovnu ekonomiju i preduzetništvo.

Kim, S. (2002). Participative management and job satisfaction: Lessons for management leadership. Public Administration Review, 62(2), 231-241.

Kouzes, J. M., Caldwell, D. F., \& Posner, B. Z. (1983). Organizational culture: How it created, maintained, and changed. Paper presented at the OD Network National Conference, October 9, 1983, Los Angeles.

Kovač, V. (2004). The concept of management of higher education institutions to support the implementation of quality assurance. PhD Thesis, Faculty of Philosophy, Rijeka.

Middlehurst, R., \& Elton, L. (1992). Leadership and management in higher education. Studies in Higher Education, 17(3), 251-264.

Morgan, G. (1997). Images of Organisation. Newbury Park, CA: Sage Publications.

Mullins, L. (1999). Management and Organisational Behaviour (5th ed.). London: Financial Times Pitman Publishing.

O'Reilly, C. (1983). Corporations, Cults, and Organizational Culture: Lessons from Silicon Valley Firms. Paper presented at the Annual Meeting of the Academy of Management, Dallas, Texas.

Petz, B. (1992). Psihologijski rječnik. Zagreb: Školska knjiga.

Schein, E. (2004). Organisational Cullture and Leadership. Thousand Oaks, CA: Sage Publications.

Schonfeld, I. S. (2000). Short research paper: An updated look at depressive symptoms and job satisfaction in first-year women teachers. Journal of Occupational and Organizational Psychology, 73(3), 363-371. doi: 10.1348/096317900167074

Shann, M. H. (1998). Professional Commitment and Satisfaction among Teachers in Urban Middle schools. The Journal of Educational Research, 92(2), 67-73.

Sousa-Pouza, A., \& Sousa-Pouza, A. A. (2000). Wellbeing at work: A cross-national analysis of the levels and determinants of job satisfaction. The Journal of Socio-Economics, 29, 517-538. doi: 10.1016/S10535357(00)00085-8

Staničić, S. (2002). Kompetenčni profil "idealnega" ravnatelja. Sodobna pedagogika, 53(119), 168-182.

Staničić, S. (2006). Menadžment u obrazovanju. Rijeka: vlastita naklada.

Van Maanen, J., \& Barley, S. R. (1983). Cultural Organization: Fragments of a Theory. Paper presented at the Annual Meeting of the Academy of Management, Dallas, Texas.

Weihrich, H., \& Koontz, H. (1998). Menadžment (10th ed.). Zagreb: MATE.

Wilderom, C. P. M., Glunk, U., \& Maslowski, R. (2000). Organisational Culture as a Predictor of Organisational Performance. In N. M. Ashkanasy, C. P. M. Wilderom \& M. Peterson (Eds.), Handbook of organizational culture and climate (pp. 193-209). Thousand Oaks, CA: Sage.

Wolk, S. (2008). Joy in School. Educational leadership, 66(1), 8-14.

Wong, C. S., Wong, P. M., \& Peng, K. Z. (2010). Effect of middle-level leader and teacher emotional intelligence on school teachers' job satisfaction: The case of Hong Kong. Educational Management, Administration and Leadership, 38(1), 59-70.

Wren, D. A., \& Voich, D. J. (2001). Menadžment proces, struktura i ponašanje. Beograd: Grmeč Privredni pregled.

Zaleznik, A. (2004). Managers and leadres: are they diferent. Harvard Busines Review, 82(1), 74-81. 